\title{
AL-IḤSAN AL-QUR'AN PERSPECTIVE (A Study of Thematic Interpretation)
}

\author{
Umar $^{1}$ \\ $\operatorname{Mardan}^{2}$ \\ Kasjim Salenda ${ }^{3}$ \\ Aan Farhani ${ }^{4}$ \\ Alauddin State Islamic University of Makassar, Indonesia ${ }^{1,2,3,4}$ \\ emailkorespondensigmail.com
}

\begin{abstract}
This study aims to provide a comprehensive understanding of al-Ihssān in the view of the Koran. The less harmonious relationship in society encourages researchers to conduct research on the concept of al-Ihsān from the perspective of the Koran. The main problem of this research is how is al-Ihsān the perspective of the Qur'an? The main problems, namely 1) What is the nature of al-Iḥsān from the perspective of the Koran?; 2) What is the form of al-Ihsān in the study of the Koran?; and what is the urgency of al-Ihsān in the view of the Qur'an? This research is library research or library research that is descriptive qualitative. The sources of data used are verses of the Qur'an, books of interpretation and hadith as well as other scientific books. This research uses a science of interpretation approach with thematic interpretation method (maudūīi). The data obtained were collected and sorted accordingly. The technique of analyzing and presenting data is done by content analysis. From the description and analysis carried out in the research, it is concluded that alIhsān from the perspective of the Koran is the best form of human action performed perfectly. Al-Ihsān is a plus (more) value of the best deed done according to its level. The best deeds are carried out both towards God, fellow human beings, and the natural environment. The actualization of ihsān is carried out with knowledge, solemnity, and sincerity and is manifested in the form of his personality integrity. All actions taken will be intended as a form of worship to Allah swt. For humans and other creatures created by Allah, it will provide more benefits and favors than doing justice. All these best deeds will continue to be improved for the sake of self-perfection.
\end{abstract}

Keywords: Al-Iḥsān; The perspective of the Qur'an; Thematic Interpretation

\section{INTORODUCTION}

In the introduction contains the importance of research, previous research at least uses the latest journal references in the last 10 years that are relevant to the research and includes the phenomena of the research being studied, research reasons, problem formulation and research objectives. ${ }^{1}$

Al-Qur'an as the word of Allah swt. has been constantly studied throughout history, by both those who believed in it and those who did not. However, the values contained in the Qur'an never dry up, the more it is studied, the wider the values it

${ }^{1}$ Russel Stannard, God of the 21st Century, trans. Happy Susanto (Yogyakarta: Cultural Scrub, 2004), p. 206 
contains. An intense study of its values is expected to be able to find new paradigms, directions, and new conceptions. ${ }^{2}$ The Qur'an is also mentioned by various experts as one of the miracles of the Prophet Muhammad's apostolate. in managing the morality of the world. This miraculous phenomenon can be seen in the name, substance, and authenticity of the text throughout the life of this universe. ${ }^{3}$ Therefore, the concept of ihsān is one of the morality contained in the Qur'an.

In Islam, it is known that there are three stages, namely: ỉman, Islam and ihsān. At the stage of faith, a person believes and fully believes in the presence of God. Through this belief, a person then enters the stage of Islam, which is to obey the religious law which contains laws and regulations as well as procedures for worship and muamalat as orders from the God he believes in. By carrying out religious law at this second stage, one is expected to enter the next stage, ihsān. This stage is the stage of human selfactualization based on an intense relationship with God personally, accepting His mandate as His representative, then carrying out the task of caliphate, namely prospering, prospering and saving their lives on earth.

Applying Islam in life means integrating faith, Islam and ị̣sān as a whole. So far, many Muslims have focused only on faith and Islam. Strive for perfect faith, stay away from shirk. Trying to make Islam complete by carrying out worships, especially those that are obligatory intensely. However, sometimes because of efforts to uphold faith and Islam, he forgets to apply ihsān, namely doing good sincerely, doing good as if he sees Allah, and if not, believing that Allah sees whatever he does. ${ }^{4}$

Every Muslim knows for sure that Islam is not valid without faith, and faith is incomplete without iḥsān. On the other hand, ị̣sān is impossible without ìmān, and ìmān is also impossible without Islam. In further study by experts, it turns out that the meanings between the three terms are related to one another, even overlapping so that every one of the three terms contains the meaning of two other terms. In ìmān there are Islam̄m and iḥsān, in Islamm there are ìmān and ihsāan, and in ihsān there are ìmān and islā $\mathrm{m}$. From this point of view, we see faith, Islam, and ihsān as a trilogy of divine teachings. ${ }^{5}$

In Islamic teachings, the benchmark for determining the good and bad value of an action is based on the Qur'an and hadith. the measure of good and bad is divine law. Work is said to be good if it is in accordance with God's commands, and actions are said

${ }^{2}$ Abd. Muin Salim, et al., Research Methodology of Mauḍūí Interpretation (Cet. I; tt: Pustaka Arif, 2010), p. 1. See also Muhammad Galib M., Ahl al-Kitab: Its Meaning and Scope (Jakarta: Paramadina, 2000), p. 2.

${ }^{3}$ Umar Shihab, Contextuality of the Qur'an; Thematic Study of Legal Verses in the Qur'an (Cet. I; Jakarta: Penamadani, 2003), p. xx.

${ }^{4}$ Muḥammad ibn Ismā'il al-Bukhārī, Șạịị al-Bukhārī, Volume I (Cet. I; Mecca: Dār Ṭauq alNajāh, 1422 H), p. 19. Hereinafter referred to as al-Bukhāri, Șahịị al-Bukhārì. See also Muslim ibn alHajjāj, Ṣahị̣ Muslim, Volume I (Beirut: Dār al-Iḥyā' al-Turās al-'Arabì, t.th .), h. 36. Hereinafter referred to as Muslim, Sahịi hus Muslim.

${ }^{5}$ Nurcholish Madjid, Complete Works of Nurcholish Madjid; Islam, Indonesianness, and Modernity, ed. Budhy Munawar-Rachman (Cet. I; Jakarta: Nurcholish Madjid Society, 2019), p. 1611. Hereinafter referred to as Nurcholish, Complete Works. 
to be bad, if they contradict and violate God's commands and forbid what God has forbidden. ${ }^{6}$

So important is ihsān, viewed from the theological aspect, it is a command of Allah that must be carried out by every Muslim. This is stated in His word QS alNahl/16: 90 .

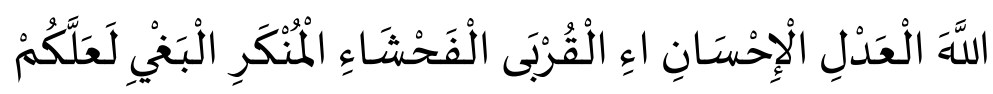

The translation:

"Verily, Allah commands (you) to do justice and do good, to give help to relatives, and He forbids (to do) vile deeds, evil and enmity. He teaches you so that you can take lessons."

In this verse, Allah swt. commanded humans to act fairly, do iḥsān, and provide assistance to relatives. All three of these lead to the act of ihsān. Fair according to alRāgib al-Așfahāni is giving something as it should and receiving as it should, while ihsan is giving more than it should and receiving as it should or giving as it should. and receive less than they should. ${ }^{8}$ Thus, the meaning of iḥsān is higher than fair. Iḥsān already includes the meaning of fair while fair does not include the meaning of ihsān. Likewise, ihsān already includes the meaning of giving assistance to relatives because it is one of the objects ${ }^{9}$ and characteristics of the muhsin. ${ }^{10}$

Uhsān to God and humans is important and needs to be guarded. If humans do not do ihsañn to Allah and fellow human beings, then they will feel humiliation, Allah's wrath, and humiliation. ${ }^{11}$ Therefore, humans should establish good relations with God and good relations with fellow humans in the form of ihsān so that humiliation, wrath from God, and misery can be avoided.

So far, the issue of ị̣sān has been forgotten by many Muslims. Whereas the mission of the Prophet on the surface of this earth is the mission of forming good morals ${ }^{12}$. Problems or problems in society are sought for guidance from the Prophet. Have faith according to the instructions of the Prophet. Worship according to the instructions of the Prophet. But neglecting to look for ways the Prophet interacted with his companions or with fellow human beings in many levels. The good character and behavior of the Prophet are found in various dimensions of life. The Messenger of Allah

${ }^{6}$ Hafid Rustiawan, "Perspectives on the Meaning of Good and Bad", p. 134.

${ }^{7}$ The Ministry of Religion of the Republic of Indonesia, the Qur'an and its translation (Cet. III; Jakarta: CV. Al Mubarok, 2018), p. 277.

${ }^{8}$ Abū al-Qāsim al-Husain ibn Muhammad, al-Mufradāt fî Garīb al-Qur'ān (Cet. I; Beirut: Dār alQalam, 1412 H ), h. 156. Hereinafter referred to as al-Rāgib al-Asfahānī, al-Mufradāt.

${ }^{9}$ See QS al-Baqarah/2:83 and QS al-Nisā'/4:36.

${ }^{10}$ See QS al-Baqarah/2:195 and Ali 'Imrān/3:134.

${ }^{11}$ See QS Āli 'Imrān/3: 112.

${ }^{12} \mathrm{Abū}$ Bakr Aḥmad ibn Ḥusain ibn 'Ali al-Baihaqī, al-Sunan al-Kubrā, vol. 10 (Cet. III; Beirut: Dār al-Kutub al-'Ilmiyyah, 1424 H/ 2003 AD), p. 323. 
who always smiled before speaking in all conditions and taught that smiling when meeting with others is charity ${ }^{13}$.

Ihsān in the view of Sufism is a noble position and the highest degree achieved by a believer when he has arrived at the perfection of faith and Islam. When a believer has reached the degree of ihsān in worshiping Allah as if he sees and is seen by Him, so that ihsān behavior will be actualized in all aspects of life that always upholds kindness and does good deeds. Ihsān becomes a position that is coveted by every believer, so it is as if to arrive at that position a believer must first perfect his faith and Islam. The faith and Islam of a believer are actualized through the pillars of faith and Islam which are believed and become the basis of adherents of Islam.

From the review of these various aspects, conducting a study of ihsān in the Qur'an is important. This is because humans have an obligation to perform ihsan in dealing with God, humans, animals, and the environment. Understanding the concept of ihsān well and then actualizing it, then of course human life and the universe can be harmonious. Thus, humans can become the ideal caliph according to the Qur'an.

Based on the background of the problem above, the main problem in this research is formulated, namely "How is Ihsān in the perspective of the Qur'an?" To answer the main problem thoroughly, it is necessary to describe it into sub-problems as follows; What is the nature of ihsān in the perspective of the Qur'an? How does ihsān form in the study of the Qur'an? What is the urgency of ihsān in the view of the Qur'an?

\section{LITERATURE REVIEW}

On a theoretical review avoid using too much numbering. We recommend using hierarchical numbering. Like :

\section{A. Definition of Ihsān}

Etymologically ihsān is maṣdar of fi'lsuläsì mazid bi ḥarf ${ }^{14}$ namely - - احسانا . It comes from fi'lsulāisi mujarrad ${ }^{15}$ that is from the word - يحسن - which means good or good and beautiful. ${ }^{16}$ The word hasuna which comes from three letters, namely -- is the opposite of al-qubh (evil). ${ }^{17}$ Hasuna also means to increase (a lot) and perfect. ${ }^{18}$ So, hasuna language means good, beautiful, increasing (a lot), and perfect.

${ }^{13}$ Al-Tirmiżi, Sunan, vol. IV, p. 339.

${ }^{14}$ Fi'lsulassi mazid bi harf is a three-letter verb that adds one letter to make four letters.

${ }^{15}$ Fi'lsuläsi mujarrad is a three-letter verb that does not get an additional letter.

${ }^{16}$ Mahmud Yunus, Arabic - Indonesian Dictionary (Jakarta: Foundation for Organizing Translators and Interpreters of the Qur'an, 1972), p. 103. Hereinafter referred to as Jonah, Dictionary. See also Majma' al-Lugah al-'Arabiyyah Egypt, al-Mu'jam al-Wasịt (Cet. IV; Egypt: Maktabah al-Syurūq alDauliyyah, 1425 H/2004 CE), p. 174.

${ }^{17} \mathrm{Abu}$ al-Husain Ahmad ibn Fāris ibn Zakariyyā, Mu'jam Maqāyīs al-Lugah, vol. II (tt: Dār alFikr, 1399 H/1979 AD), p. . 57. Hereinafter referred to as Ibn Faris, Maqāyīs. See also Ibn Manzūur, Lisān al-'Arb, Volume II (Cairo: Dār al-Ma'ārif, t.th.), p. 878.

${ }^{18}$ Aḥmad Mukhtār 'Umar, Mu'jam al-Lugah al-'Arabiyyah al-Mu'āṣarah, vol. I (Cet. I; Cairo: 'Ālam al-Kutub, 1429 H/2008 M), h. 497. 
From the word hasuna, three popular words emerge, namely husn, hasanah, and husnā. According to al-Rāgib al-Asfahānì (d. $502 \mathrm{H})$, husn is an expression of all things that are happy and expected whose measure is reason, lust, and feeling; hasanah is an expression about everything that is pleasant in the form of favors that humans get on themselves, their bodies, and their conditions, which is the opposite of sayyiah ( $\sin )$; and husnā (heaven ${ }^{19}$ ) is the opposite of sūa (Hell of Hell ${ }^{20}$. The difference between the three is that husn is used for something material and non-material, hasanah if it is in the form of an attribute then it is used for something that is material and non-material, but if it is an ism (noun) then it is used for something that is non-material, while husna is only used for something that is non-material. Furthermore, al-Rāgib al-Asfahāni argued that in general the use of the word husn mostly refers to something that is considered good by the eye such as rajul hasan (handsome man) and imra'ah h. asanah (beautiful woman), but its use in the Qur'an refers more to something that is considered good according to reason, such as al-lazīina yastami'ün al-qaul fa yattabi' ${ }^{21}$

Word whichplus one letter (mazid bi harf) to form the word . Linguistically it means to do something good antonym of the word asā'a (doing something bad). In addition, it also means to beautify, beautify, and give pleasure. ${ }^{22}$ From that word comes the word ان which is the mașdar of him. Ihsān is the opposite of isá'ah (to do bad). ${ }^{23}$ According to al-Rāgib al-Așfahāni, ihsān has two meanings: 1) giving favors to others, and 2) beautifying deeds. This second meaning occurs when he has good knowledge or carries out good deeds, such as the words of amïr al-mu'minin ra., al-nās abnā' mā yuhsinūn (humans are children -good children), meaning they are attributed to what they know or what they practice in the form of good deeds. ${ }^{24}$ A similar meaning was also expressed by Ibn Hajar al-'Asqalāni (d. 1449 AD) that ị̣sān which is mașdar becomes muta'addi ${ }^{25}$ by itself and muta'addi with others. Muta'addi by itself is like then it means (I did it perfectly) and muta'addi with others like فلان الي then it means التفع اليه اوصلت (I gave him the benefit). ${ }^{26}$ The word that becomes muta'addi with another uses hurūf jarr الليه or . So, the word ahsana when standing alone means doing good deeds

\footnotetext{
${ }^{19}$ Husna $\bar{a}$ which means heaven is obtained from the interpretation of QS al-Lail/92: 6. See Ibn Manzūur, Lisān al-'Arb, Volume II, p. 877.

${ }^{20}$ Ibn Manzūur, Lisān al-'Arb, Volume II, p. 877.

${ }^{21} \mathrm{Abū}$ al-Qāsim al-Husain ibn Muhammad, al-Mufradāt fì Garīb al-Qur'ān, Volume I (Mecca: Maktabah Nizār Muștafā al-Bāz, t.th.), p. 155-156. Hereinafter referred to as al-Rāgib al-Asfahānī, alMufradāt.

${ }^{22}$ Majma' al-Lugah al-'Arabiyyah of Egypt, al-Mu'jam al-Wasiț, p. 174. See also Aḥmad Mukhtār 'Umar, Mu'jam al-Lugah al-'Arabiyyah al-Mu'āṣarah, vol. I, p. 497.

${ }^{23}$ Ibn Manzūur, Lisān al-'Arb, Volume II, p. 878.

${ }^{24}$ Al-Rāgib al-Asfahānī, al-Mufradāt, Volume I, p. 156.

${ }^{25}$ Muta'addi is a verb that initially does not require maf'ūl (object) when it has been muta'addikan then it becomes a verb that requires maf'ùl.
}

${ }^{26}$ Aḥmad ibn 'Ali ibn Ḥajar al-'Asqalānī, Fatḥ al-Bārī Sharh Șahịị al-Bukhārī, volume I (Beirut: Dā r al-Ma'rifah, 1379 H), p. 120. Hereinafter referred to as al-'Asqalāní, Fath al-Bārì. See also Muhammad ibn Aḥmad ibn Abū Bakr al-Qurțubi, al-Jāmi' li Ahkām al-Qur'ān, vol. 10 (Cet. II; Cairo: Da r al-Kutub al-Mișriyyah, 1384 H/1964 AD), p. 166. Hereinafter referred to as al-Qurțubì, al-Jāmi'. 
perfectly, beautifying, and beautifying. Meanwhile, when coupled with the letter jarr, then it means giving benefits.

The meaning of iḥsān as doing something good is described in QS al-Isrā'/17: 7.

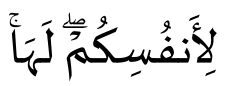

The translation:

"If you do good (meaning) you do good for yourself. And if you do evil, then (the loss of evil) is for yourself. "27

According to Fakhr al-Rāzi (w. $606 \mathrm{H}$ ) that ị̣sān in this verse is doing good/obedience and people who do good will return to themselves in the way of Allah swt. will open the door of goodness and blessings. While doing bad by doing what is forbidden the consequences will return to himself in the way of Allah swt. will open the doors of torment. In this verse, the word ahsantum (doing good) is mentioned twice while the word asa'tum (doing bad) is mentioned only once indicating that it is the mercy of Allah swt. wider than His anger. ${ }^{28}$

Ihsān It is also interpreted with sincerity which is a condition for the validity of one's faith and Islam. A person's statement of faith and acknowledgment of Islam, then he does not sincerely do good, then he cannot be called a muhsin (one who does iḥsān), even though his faith is good. And iḥsān is also meant as a term that shows al-murāqabah (fear of Allah) and obedience to Him. ${ }^{29}$ Whoever fears Allah, then he will beautify his deeds. ${ }^{30}$

Based on the etymological understanding above, the meaning of ihsān can be divided into five meanings. First, iḥsān means doing good deeds in general; second, iḥsān means beautifying and perfecting; third, iḥsān means to give favors; fourth, ihsāan means sincere; and fifth, iḥsān means fear and obedience to Allah swt.

Terminologically, the notion of ihsān boils down to the explanation of the Prophet Muhammad. when defining iḥsān as an answer to the Angel Gabriel's question.

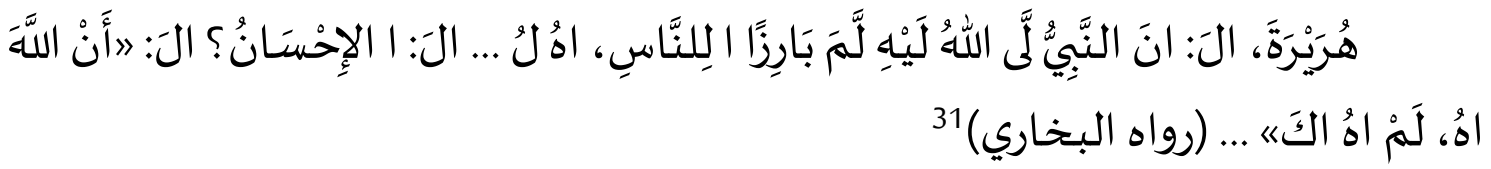

\footnotetext{
${ }^{27}$ The Ministry of Religion of the Republic of Indonesia, the Qur'an and its translation (Cet. III; Jakarta: CV. Al Mubarok, 2018), p. 282.

${ }^{28} \mathrm{Abū}$ 'Abdullah Muḥammad ibn 'Umar ibn al-Ḥasan ibn al-Ḥusain al-Rāzī, Mafātīh al-Gaib, vol. XX (Cet. III; Beirut: Dā r Ihỵā' al-Turās al-'Arabī, 1420 H), p. 301. Hereinafter referred to as Fakhr alRāzì, Mafätịh.

${ }^{29}$ Ihsān which means sincerity is obtained from the Prophet's hadith which says ka annaka tarāh (as if you see Him), while ihsān which means fear and obedience to Allah is obtained from the hadith fa in lam takun tarāh fa innahu yarā k (if you do not see it, indeed He sees you).

${ }^{30}$ Ibn Manzūur, Lisān al-'Arab, vol. II, p. 878-879.

${ }^{31}$ Muhammad ibn Ismā'il al-Bukhārī, Șaḥiḥ al-Bukhārī, Volume I (Cet. I; Mecca: Dār Ṭauq alNajāh, 1422 H), p. 19. Hereinafter referred to as al-Bukhārì, Șahịị al-Bukhārī.
} 
It means:

"From Abu Hurayrah said: "One day the Prophet. went out to meet humans and was visited by Jibril .... (Jibril) asked: "What is ihsān?" (The Prophet) replied: "You worship Allah as if you see Him, if you do not see him, indeed He sees you ..." (HR. Al-Bukhärī)

Commenting on this hadith, Ibn Ḥajar al-'Asqalāni gives the definition that Iḥsān has two meanings. First, do something perfectly; and second, to benefit others. Ihssān referred to in this hadith is the first meaning, because what is desired in worship is to do it as well as possible and as perfect as possible. In this hadith, there are two meanings indicated by the word Ihsān, namely believing in the presence of Allah with his heart so that it is as if he saw it with his eyes and felt the presence of Allah that Allah is always watching him see everything he does. ${ }^{32}$ Thus, understanding the two meanings of ịsān in the hadith can make a person always improve his worship to Allah because he feels God's presence and feels supervised by Him. It will even have an impact on his daily life who always does everything as well and as perfectly as possible.

\section{B. Term Ihsān and its derivation in the Qur'an}

InAl-Qur'an, the word ị̣sān along with its derivation is repeated 72 times in 29 surahs. The details are the word ạ̣sana which is fi'l mạḍi (past verb) of ihsān repeated 17 times, yuhsinu which is fi'l mudāari' (verb now/future) of ihsān is repeated 2 times, ahsin which is a fi'l 'amr (command verb) of ihsān is also repeated 2 times, the word ihsān itself which is mașdar from ahsana is repeated 12 times, and the word muhsin as ism fá'il (subject) of ihsān is repeated 39 times.

\section{Ihssān}

The vocabulary of ihsān is mașdar from the word ahsana. Arabic grammar stipulates that mașdar functions as its fi'l function. This means that the word ihsān contains the subject muhsin as it applies to the fi'l. Ihsān as ism implies something that is permanent and ongoing, ${ }^{33}$ does not occur temporarily and is fictitious.

The word ihsān is repeated in the Qur'an 12 times in 11 verses and 8 suras, namely QS al-Baqarah/2: 83, 178, and 229, QS al-Nisā̄/4: 36 and 62, QS al-An'ām/6:151, QS alTaubah/9: 100, QS al-Naḥ1/16: 90, QS al-Isrāañ17: 23, QS al -Ahqāf/46: 15, and QS alRahmān/55: 60. Not every application in every verse has a discussion in the same context. Seven of these verses deal with a variety of different themes, ${ }^{34}$ while five of them relate to the theme of doing good to both parents. ${ }^{35}$

${ }^{32}$ Al-'Asqalānī, Fath al-Bārī, vol. I, p. 120.

${ }^{33}$ Al-Suyūtị, al-Itqān, volume I, p. 633.

${ }^{34} \mathrm{QS}$ al-Baqarah/2: 178 talks about ihsān in paying the ransom, QS al-Baqarah/2: 229 talks about ihsān in divorcing a wife, QS al-Taubah/9:100 about ihsā $\mathrm{n}$ in following in the footsteps of the Muhajirin and Ansar, QS al-Naḥl/16: 90 about the command to do iḥsān, QS al-Raḥmān/55: 60 about the retribution for iḥsān behavior, and QS al-Nisā'/4:62 about the oath of hypocrites to do iḥsān.

${ }^{35}$ The five verses are QS al-Baqarah/2: 83, QS al-Nisā'/4: 36, QS al-An'ām/6: 151, QS al-Isrā'/17: 23, and QS. al-Ahquāf/46: 15. 


\section{Ahsana, ahsanū, and ahsantum}

The word ihsān in the form of fi'l mạḍi (a verb that shows the past) is listed in the Qur'an 17 times. The details are that the word ahsana is listed 9 times spread over 9 verses and 8 suras. ${ }^{36}$ The fa'til (subject) in the form of ism zāhir (noun/personal name), namely Allah swt. written twice, in QS al-Qașaș/28: 77 and al-Ṭalāq/65: 11. And the Fa'il is in the form of ism al-ḍamir al-gạib li al-mufrad (pronoun third party) is mentioned in the Qur'an seven times in seven verses and seven suras, namely QS al-An'ām/6: 154, QS Yūsuf/12: 23 and 100, QS al-Kahf/18 : 30, QS al-Sajdah/32: 7, QS Gāfir/40: 64, and QS al-Tagābun/64: 3 .

As for ahsanū the fa' 'ifit is in the form of al-damìr al-gāib li al-jam' al-mużakkar (a third party pronoun for men that shows a lot) is listed six times ${ }^{37}$, in six verses and six suras, namely QS Ali 'Imrān/3:172, QS al-Māidah/5: 93, QS Yūnus/10: 26, QS alNaḥl/16: 30 , QS al-Zumar/39:10, and QS al-Najm/53: 31. Meanwhile, ạsantum whose fa'il is in the form of damīr al-mukhâtab li al-jam' ( second-party pronouns that show many) are repeated twice in QS al-Isrä'/17: 7.

Ihsān in the form of fi'l māđì (ahsana, ahsanū, and ahsantum) shows iḥsān actions that have been carried out in the past. Ihsān in this category is temporal, fluctuating, and undergoes changes or recognizes dynamics. The degree of possibility between iḥsān being carried out by someone consistently or not and between increasing its implementation or not, because "disclosure of fi'l for a term indicates the emergence of something new and the occurrence of an action". ${ }^{38}$ Another term is fi'l which has the character of harakah (moving, recognizing changes, or experiencing dynamics). In QS al-Kahf/18: 30 it is stated,

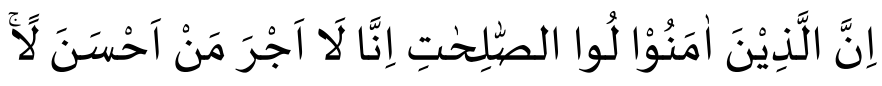

The translation:

"Indeed, those who believe and do good deeds, We will not waste the reward of those who do good deeds. "'39

3. Yuhsinūn and Tuhsinū

In the Qur'an there is a derivation of the word muhsin in the form of fi'l mudari' (a verb indicating the present and the future) with different fá'il. The words yuhsinūn and tuhsinu are contained once each. Yuhsinūn whose fá'il is in the form of al-damir algàib li al-jam' al-mużakkar (a third-party pronoun that shows a lot for men) there is one times in QS al-Kahf/18: 104.

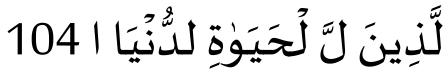

\footnotetext{
${ }^{36 \prime}$ Abd al-Bāqìi, al-Mu'jam, p. 202.

${ }^{37}$ Abd al-Bāqìi, al-Mu'jam, p. 202.

${ }^{38}$ Jalāluddin 'Abduraḥmān al-Suyūṭi, al-Itqān fî̀ 'Ulūm al-Qur'ān, volume I (Beirut: Dār Ibn Kasīr, 1996), p. 199. Hereinafter referred to as al-Suyūṭi, al-Itqān.

${ }^{39}$ Ministry of Religion of the Republic of Indonesia, the Qur'an and its translation, p. 297.
} 
The translation:

"Namely people whose actions in the life of this world are in vain, while they think they have done their best. "

This verse talks about the futile practices of the disbelievers, where they think that it is the best deeds they do, but Allah swt rejects them. for not believing in Him and rejecting the day of vengeance. Though every practice should generate profit. For Muslims, the expected profit is the ukhrawi profit. And it would be even better if the worldly gains merged with the ukhrawi, and of course if that profit is not achieved, the capital will be wasted, at least the time and energy capital.

According to Quraish Shihab (b. 1944 AD), the use of the word (misguided) in the verse indicates the loss of their efforts. That's because their efforts were in vain and did not reach the target. A person may not reach the target due to lack of experience and practice, or a mistake in finding a path, or any other factor. As long as the person concerned is aware of the mistakes and shortcomings that resulted in the loss, it is hoped that this can still be corrected, even though the loss has occurred. However, if the person concerned does not realize his loss, even feels that he has done the best he can or feels that he has been lucky, surely he is not just one of the losers, but the one who loses the most. This is what happens a lot to those who are mesmerized and mesmerized and fixated on the beauty of worldly life. Like someone who managed to steal and gain material gains, who thought he had made a profit when it was actually a loss. Or someone who worships idols, he thinks that his worship can bring benefits, but it turns out that it is not only the benefits that he does not get but the losses and accidents he suffers. ${ }^{41}$

4. Aḥsin and Aḥsinū

SecondThis vocabulary is in the form of fi'l amr (command verb) which has a second-party subject pronoun. The second subject hints at the meaning of muhsin, because he is the target of God's command to do ihsan consistently in order to become muhsin in accordance with the use of fi'l amr which contains the meaning of talab (demand to be done). The term ahsin which has a singular subject pronoun is listed in the Qur'an once in QS al-Qașaș/28: 77.

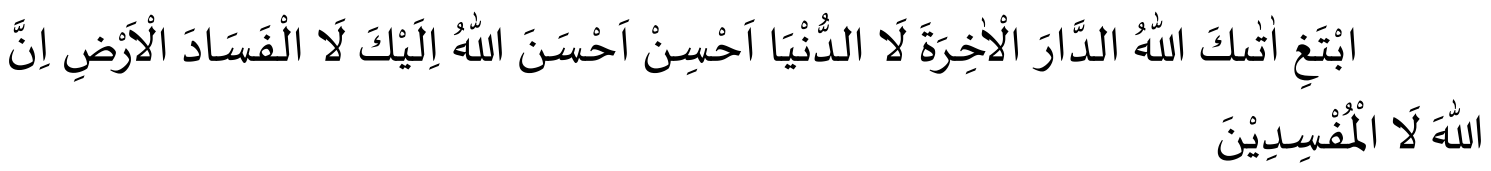

Translate:

"And seek (reward) the land of the Hereafter with what Allah has given you, but do not forget your share in this world and do good (to others) as Allah has done good to you, and do not do mischief on earth. Indeed, Allah does not like those who do mischief." 42

${ }^{40}$ Ministry of Religion of the Republic of Indonesia, the Qur'an and its translation, p. 304.

${ }^{41}$ Quraish Shihab, al-Misbah, vol. 7, p. 385-386.

${ }^{42}$ Ministry of Religion of the Republic of Indonesia, the Qur'an and its translation, p. 394. 


\section{Terms That are Equivalent in Meaning to Ihsān, Their Differences and Similarities}

1. Al-'Adl

The term 'adl and its derivations are repeated in the Qur'an 28 times in 28 verses and 10 suras. ${ }^{43}$ While the word 'adl in the form of masdar is mentioned 14 times in 14 verses and seven suras. The word al-'adl has two conflicting original meanings, namely istiwā' or straight and i'wijāj or crooked. ${ }^{44}$ The word formed from the letters 'ain, dāl, and lām is used in the Qur'an with both meanings, but what is meant here is the word al-'adl with the meaning al-istiwā' (straight). . To do justice to something means to do righteously; in the sense that without causing harm by giving the same decision or treatment according to the size or measure.

\section{Al-Säct}

This vocabulary comes from șalaḥa - yaṣluhu - șulḥan - șalāham - șulūḥan which means good, not damaged, not perishable, worthy, useful, and peace. ${ }^{45}$ The term sălih and its derivation are contained in the Qur'an 295 times ${ }^{46}$ classified into words that have multiple or multiple meanings. Of that number, there are three verses that connect piety with ị̣sān. QS al-Māidah/5: 84-85 are two verses contained in both of them the link between al-săalihịin listed in verse 84 with al-muhsinin recorded in verse 85 . Al-șāliḥin (people who like to do good deeds) is an attribute for al-muhsinin who deserves a reward in the form of heaven. ${ }^{47}$ Moreover, al-ṣāliḥin represent individuals who do not merely carry out orders and leave Allah's prohibitions, more than that, they continuously and consistently carry out what He has prescribed. ${ }^{48}$ This is a sign that in a pious person there are beautiful and noble qualities, including mawaddah (love) that is free from various forms of envy.

\section{Al-Birr}

Al-Birr comes from the word barra which consists of the letters ba, and two ra have 4 meanings, namely: true, the story of the sound, the opposite of the word sea, and plants. ${ }^{49}$ In the Qur'an the term al-birr and its derivations are repeated 32 times. ${ }^{50}$ In its use, the word al-birr can mean to accept as in the expression barrallahhajjaka (God accepts your Hajj), it can also mean obedience like the expression yabarru rabbahu, meaning yuṭi'i'uhu (obey Him). ${ }^{51}$ According to al-Rāgib al-Asfahānì, al-birr is the breadth

${ }^{43}$ 'Abd al-Bāqìi, al-Mu'jam, p. 448-449.

${ }^{44}$ Ibn Faris, Maqāyīs, vol. IV, p. 246.

${ }^{45}$ Yunus, Dictionary, p. 219-220.

${ }^{46}$ 'Abd al-Bāqìi, al-Mu'jam, p. 411-413.

${ }^{47}$ Abū Ḥayyān, al-Baḥr al-Muhịị, vol. IV, p. 348.

${ }^{48}$ Aḥmad ibn Yūusuf al-Samīn al-Halabī, 'Umdah al-Ḥuffāz fí Tafsīr Ashraf al-Alfāz, vol. II (Cet. I; Beirut : Dằr al-Kutub al-'Ilmiyyah, 1417 H/1996 M0̄ p. 347.

${ }^{49}$ Ibn Faris, Maqāyīs, vol. I, p. 177.

${ }^{50 \prime}$ Abd al-Bāqìi, al-Mu'jam, p. 149.

${ }^{51}$ Ibn Faris, Maqāyīs, vol. I, p. 177. See also Ibn Manzūur, Lisān, vol. IV, p. 51. 
of heart in doing good. The word is sometimes attributed to Allah swt. as in QS alTTur/52: 28 innahu huwa al-barr al-rahim (He is the One who bestows goodness, is most merciful). And it can also be attributed to humans like the expression barra al-'abdu rabbahu which means tawassa'a fî tạ'atihi (roomy in obeying Him). ${ }^{52}$ So, al-birr is obedient in carrying out the truth.

\section{Itqān}

The word itqān is maṣdar from fi'lsulāsìi mazid اتقانا - - اتقن which means (to do perfectly). ${ }^{53}$ It comes from the letters tä', qäf, and nūn which have 2 meanings, namely: first, to do something perfectly, and the second meaning is soil and mud. ${ }^{54}$ In Lisan al'Arabic the word tiqn is the name for a man from the tribe of 'Ad, someone who is good at shooting and the bullet never drops, misses, or strays before hitting the target so that at that time everyone who was accurate or professional at work was given tiqn name. ${ }^{55}$ So, the word itqān means to do something as well as possible and as perfect as possible.

\section{Al-Ma'rüf}

The word ma'rü is mentioned in the Qur'an 39 times in 11 suras in various places and in various contexts. ${ }^{56}$ The word ma'ruf comes from Arabic, the same as the word 'urf (customs). Linguistically, it means knowing. ${ }^{57}$ It is equivalent in meaning to the word al'ilm which means knowledge. However, according to al-Rāgib al-Așfahāni (d. 502 H), the word al-ma'rifah is more specific than al-'ilm. Al-Ma'rifah is knowing something by thinking about and exploring the influence of something, the antonym is al-inkār. In the Arabic-Indonesian dictionary, ma'rūf means virtue, goodness, well-known, known. ${ }^{58}$ Whereas in al-Mu'jam al-Wasit, ma'rü is defined as every good deed according to reason or the Shari'a. ${ }^{59}$ So, ma'rü is relative goodness (conditional). It will not be the same as ma'rü in one place with ma'rūf in another.

\section{Ihsān in The View of The Ulama}

The meaning of iḥsān has also been carried out by many scholars and commentators. In interpreting ihsān, there are several different views expressed. According to Ibn Manzūr (w. $711 \mathrm{H}$ ) that ihsān is the opposite of isāah or doing evil. ${ }^{60}$ This view is the meaning of ihsān in general, which includes all actions that do not contain evil. In addition to this meaning, according to him, ihsān also means sincerity.

\footnotetext{
${ }^{52}$ Al-Rāgib al-Asfahānī, al-Mufradāt, p. 114.

${ }^{53}$ Majma' al-Lugah al-'Arabiyyah of Egypt, al-Mu'jam al-Wasit, p. 86.

${ }^{54}$ Ibn Faris, Maqāyīs, vol. I, p. 350.

${ }^{55}$ Ibn Manzūur, Lisān al-'Arab, vol. I, p. 437.

${ }^{56}$ 'Abd al-Bāqìi, al-Mu'jam, p. 458-459.

${ }^{57}$ Jonah, Dictionary, p, 263.

${ }^{58}$ Y unus, Dictionary, p. 263.

${ }^{59}$ Majma' al-Lugah al-'Arabiyyah of Egypt, al-Mu'jam al-Wasiț, p. 595. See also al-Rāgib al-

${ }^{60}$ Ibn Manzūur, Lisān al-'Arab, Volume II, p. 878.
} Aṣfahānī, al-Mufradāt, p. 561. 
This meaning was conveyed by Ibn Manzūr $(w .711 \mathrm{H})$ when he understood the term ihsān contained in QS al-Nahil/16: 90.

Ṭantāwi Jauhari also put ị̣sān as one of the pillars of religion. According to him, the religious practices numbered 60 branches. The highest branch is the sentence la ilāha illā allāh (there is no god but Allah) and the lowest is to keep something harmful (a kind of thorn) from the road. This indicates that all human actions in this world lead to the words of the Prophet. al-ihsān an ta'budallah̆h ka annaka tarāhu (ihsān is you worship Allah as if you saw Him). Therefore, ihsān includes the pillars of religion which includes faith and Islam. ${ }^{61}$

Al-Marāgi $(\mathrm{d} .1371 \mathrm{H})$ gives a description of ihsān as a form of a person's good deeds that are carried out in the best and most perfect way. According to him, the highest level of ihsān is to do good to those who do bad. Al-Marāgi quotes a narration that the Prophet Isa as. said, "Iḥsann is that you do good to those who do bad to you, and not including Ihsān, do good to those who do good to you." ${ }^{2}$ Repaying someone's good deeds with the same kindness is in the fair category. Ihsān is a trait that makes the owner treat the other party well even though the other party treats him badly. Therefore, ihsān is a goodness that is born from the deepest inner awareness. Ihsān is the embodiment of the desire to do better what other people do.

M. Quraish Shihab (b. 1944 AD) quotes the view of al-Harrāil - as quoted by alBiqā'i - that the word ihsān means the peak of good deeds. With respect to the servant, it is attained when a person sees himself in another person so that he gives for him what he should give for himself; while the ihsān between the servant and Allah is the melting away of him so that he only "sees" Allah swt. That's why the ihsan between a servant and a fellow human being is that he no longer sees himself and only sees the other person. Whoever sees himself in the position of the needs of others and does not see himself when worshiping Allah, he is called muhsin, and at that time he has reached the peak in all his deeds. ${ }^{63}$

In addition, there is also Sufyān ibn 'Uyainah $(\mathrm{d} .430 \mathrm{H})$ who argues that ihsān is the behavior of keeping something secret which is better than publishing it. ${ }^{64}$ Referring to this understanding of ị̣sān, it means more emphasis on the nature of prudence. This is because the act of expressing a kindness openly is feared to give birth to arrogance and uncontrolled popularity (riyā' or sum'ah).

Likewise, the act of publicizing the evil that can lead to the emergence of gibah (telling the bad things of others) and namimah (fights). Even though both are forms of bad morals (mażmümah). Efforts to publish and hide something should be an inherent part of human life. This application of the nature of ihsān refers to wisdom and appropriate use.

\footnotetext{
${ }^{61}$ Ṭanțāwìi, al-Jawāhir, vol. VIII, p. 173.

${ }^{62}$ Al-Marāgī, Tafsīi, vol XIV, p. 131-132.

${ }^{63}$ M. Quraish Shihab, Tafsir al-Misbah: Message, Impression, and Harmony of the Qur'an, Vol 1 (Cet. V; Jakarta: Lentera Hati, 2012), p. 248.

${ }^{64}$ Ṭanțāwìi, al-Jawāhir, vol. VIII, p. 174.
} 


\section{METHOD}

This research is library research or library research which is descriptive qualitative. The sources of data used are verses of the Qur'an, books of commentary and hadith as well as other scientific books. This study uses a science of interpretation approach with thematic interpretation method (maudūi). The data obtained were collected and sorted accordingly. The technique of analyzing and presenting data is done by content analysis.

\section{FINDING AND DISCUSSION}

In the results of the study the authors describe the results obtained from the research clearly and informatively. If using subtitles on research results, it should be arranged in a systematic and hierarchical manner. ${ }^{65}$

\section{A. The Purpose of Ihsān in The Qur'an}

Ihsān is an attitude possessed by someone who always feels supervised by Allah SWT. in every behavior. The application of this ihsan attitude will make a person always be careful in his life because he feels supervised by Allah SWT. Everything that is done with ihsān will produce maximum results and vice versa if a job is done without being accompanied by ihsan it will be done in moderation.

The essence of ị̣sān is to present God within, purify the heart, and bring goodness to all of God's creatures. Ihsān entirely contains messages of piety and human morality. Ihsān is the highest good deed and the ultimate goal of humans in life, including: Iḥsān in the face of life's trials, Iṇsān aims to always obey and obey Allah and His Messenger, Get forgiveness and the best reply from Allah SWT,

\section{B. Benefits of Ihsān in the Qur'an}

In general, Allah SWT. ordering a provision to humans is always accompanied by rewards for those who carry it out. As an expert on ihsān, everyone is stimulated by the Qur'an with a commensurate reward according to the type of activity carried out, so that in principle, people who do iḥān will get an award in the form of ihsān as well. The award is given because of the dignity of someone who does ihsān (mu .)Hsin) is at the highest level and because of the existence of the award itself which is included in God's promises that are sure to be kept, every muHsin should not doubt it, even though His promise is a mystery or a secret that is difficult to assess by logical reasoning.

The Qur'an guarantees the certainty of the award as stated in QS Hūd/11: 115.

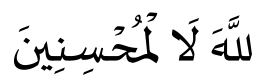

The translation:

"And be patient, for Allah does not waste the reward of those who do good."

\footnotetext{
${ }^{65}$ A. Rizki Arwansyah (32 years), Bone historian, Interview, Watampone, 20 November 2017

${ }^{66}$ Ministry of Religion of the Republic of Indonesia, the Qur'an and its translation, p. 234.
} 
Basically, the rewards or benefits promised by Allah to those who do ihsān are classified into two parts, namely the benefits obtained in this world and the benefits that will be obtained in the hereafter.

\section{CONCLUTION}

From the above explanation of ihsān in the perspective of the Qur'an, several conclusions can be drawn. Iḥsān is doing something beautifully and perfectly, so the word is translated as "beautify, improve, or perfect". Ihsān is higher than fair. Fair is giving something as it should and receiving as it should, while ihsān is giving more than it should and receiving as it should or giving as it should and receiving less than it should. Insān is an addition to the measure of justice so that fair propriety is mandatory while iḥsān propriety is sunnah. Thus, iḥsān is an added value (plus) for a good deed done. Isā $\mathrm{n}$ is also more common than in'ām (to give favor). In'àm is a good deed aimed at others while ị̣sān is a good deed aimed at both oneself and others. The form of ị̣sān in the Qur'an can be seen from ihssā n Allah and human ihsān. Among the ihsān of Allah is creating what is in the heavens and on earth as beautiful and perfect as possible. God works beauty begins with the creation of beauty itself, meanwhile, the highest beauty of God's creation is human. He makes life and life in balance, which need each other. Meanwhile, human iḥsān are required to imitate God's iḥsān in doing and acting in all good things aimed at God, fellow human beings, as well as to the environment. Ihsān to Allah SWT. mostly done in the form of worship as gratitude to Him. In addition, all forms of ị̣sān done by humans to anyone and anything, implicitly all lead to Allah SWT. because doing good to all things is His commandment that must be carried out. In the historical context, ị̣sān behavior has been practiced by the prophets and apostles of Allah where they in preaching are always patient in dealing with their people. Prophet Noah as. preaching in the midst of 950 years only a few of them believe. even these people have believed for a long time, however, Noah as. keep patient. The form of Noah's ihsān. is a strong faith in Allah, preaching well and patient with the insults of his people, and always be grateful for the blessings of Allah SWT. Ihsān Prophet Ibrahim is patient in preaching in the way of Allah and always respects his parents even though they are contrary to the side of faith. Prophet Yusuf as. also a prophet who always applies ihssān. He received bad treatment from his brothers but he did not reciprocate even treated them well. And lastly is the Prophet Muhammad who is praised by Allah as a person who has noble character. He always smiled when he met other people, even though his life was in danger, he still forgave the Taif people's treatment of him. The application of the ihsān attitude is very important in human life. People who do ihsān will always be careful in their lives, because they always feel supervised by Allah SWT. Thus, he will do his best in every activity. In addition, with the attitude of ị̣sān a person will cultivate a sincere attitude, because in carrying out his activities he only hopes for a reply and pleasure that comes from Allah SWT. A muhsin will perform ị̣sān in the face of life's trials with patience, sincerity, and gratitude as a manifestation of the person who does ihsān in his life. So that way, Allah SWT. promise the believers a happy life both in this world and in the hereafter for the good they do. because in carrying out its activities only expect a reply and pleasure that comes from Allah SWT. A muhsin will perform ihsān in the face of life's trials with patience, sincerity, and gratitude as a manifestation of the person who does iḥsann in his life. So that way, Allah SWT. promise the believers a happy life both in this world and in the hereafter for the good they do. because in carrying out 
its activities only expect a reply and pleasure that comes from Allah SWT. A muhsin will perform ihsān in the face of life's trials with patience, sincerity, and gratitude as a manifestation of the person who does ihsān in his life. So that way, Allah SWT. promise the believers a happy life both in this world and in the hereafter for the good they do.

\section{BIBLIOGRAPHY}

Stannard, Russel, Tuhan Abad 21, terj. Happy Susanto Yogyakarta: Belukar Budaya, 2004.

A. Rizki Arwansyah (32 tahun), Sejarawan Bone, Wawancara, Watampone, 20 November 2017

Abd. Muin Salim, dkk., Metodologi Penelitian Tafsir Mauḍu'ì (Cet. I; t.t.: Pustaka Arif, 2010), h. 1. Lihat juga Muhammad Galib M., Ahl al-Kitab: Makna dan Cakupannya (Jakarta: Paramadina, 2000), h. 2.

Abū 'Abdullah Muhammad ibn 'Umar ibn al-Hasan ibn al-Husain al-Rāzì, Mafâtìh alGaib, jilid XX (Cet. III; Beirut: Dār Ihyā' al-Turās al-`Arabī, 1420 H), h. 301. Selanjutnya disebut Fakhr al-Rāzì, Mafätīh.

Abū al-Ḥusain Aḥmad ibn Fāris ibn Zakariyyāa, Mu'jam Maqāyīs al-Lugah, jilid II (t.t.: Dār al-Fikr, 1399 H/1979 M), h. 57. Selanjutnya disebut Ibnu Fāris, Maqāyīs. Lihat juga Ibnu Manzūr, Lisān al-'Arb, Jilid II (Kairo: Dār al-Ma‘ārif, t.th.), h. 878.

Abū al-Qāsim al-Ḥusain ibn Muḥammad, al-Mufradāt fí Garìb al-Qur'ān (Cet. I; Beirut: Dār al-Qalam, 1412 H), h. 156. Selanjutnya disebut al-Rāgib al-Asfahānī, alMufradāt.

Abū Bakr Ahmad ibn Husain ibn 'Alì al-Baihaqī, al-Sunan al-Kubrā, jilid 10 (Cet. III; Beirut: Dār al-Kutub al-'Ilmiyyah, 1424 H/2003 M), h. 323.

Abū Ḥayyān, al-Baḥr al-Muhịị, jilid IV, h. 348.

Ahmad ibn 'Ali ibn Hajar al-'Asqalānì, Fath al-Bāri Syarh Ṣaḥị al-Bukhārì, jilid I (Beirut: Dār al-Ma'rifah, 1379 H), h. 120. Selanjutnya disebut al-'Asqalāni, Fath al-Bārì. Lihat juga Muhammad ibn Ahmad ibn Abū Bakr al-Qurțubi, al-Jāmi‘ li Aḥkām al-Qur'ān, jilid 10 (Cet. II; Kairo: Dār al-Kutub al-Miṣriyyah, 1384 H/1964 M), h. 166. Selanjutnya disebut al-Qurțubi, al-Jāmi'.

Aḥmad ibn Yūsuf al-Samin al-Halabī, 'Umdah al-Huffāz fĩ Tafsīr Asyraf al-Alfāz, jilid II (Cet. I; Beirut: Dār al-Kutub al-'Ilmiyyah, 1417 H/1996 M0̄ h. 347.

Ahmad Mukhtār 'Umar, Mu'jam al-Lugah al-'Arabiyyah al-Mu'āṣarah, jilid I (Cet. I; Kairo: 'Ālam al-Kutub, 1429 H/2008 M), h. 497. 
Husnā yang bermakna surga didapat dari penafsiran QS al-Lail/92: 6. Lihat Ibnu Manzuūr, Lisān al-‘Arb, Jilid II, h. 877.

Hafid Rustiawan, "Perspektif tentang Makna Baik dan Buruk", h. 134.

Ibnu Fāris, Maqāyīs, jilid I, h. 177. Lihat juga Ibnu Manẓūr, Lisān, jilid IV, h. 51.

Jalāluddīn 'Abduraḥmān al-Suyūṭi, al-Itqān fì 'Ulūm al-Qur'ān, jilid I (Beirut: Dār Ibn Kasīir, 1996), h. 199. Selanjutnya disebut al-Suyūṭi, al-Itqān.

Kelima ayat tersebut adalah QS al-Baqarah/2: 83, QS al-Nisā’/4: 36, QS al-An‘ām/6: 151, QS al-Isrā'/17: 23, dan QS al-Aḥāâf/46: 15.

Kementerian Agama RI, Al-Qur'an dan Terjemahnya (Cet. III; Jakarta: CV. Al Mubarok, 2018), h. 277.

M. Quraish Shihab, Tafsir al-Misbah: Pesan, Kesan, dan Keserasian al-Qur'an, Vol 1 (Cet. V; Jakarta: Lentera Hati, 2012), h. 248.

Mahmud Yunus, Kamus Bahasa Arab - Indonesia (Jakarta: Yayasan Penyelenggara Penterjemah dan Penafsir al-Qur'an, 1972), h. 103. Selanjutnya disebut Yunus, Kamus. Lihat juga Majma' al-Lugah al-'Arabiyyah Mesir, al-Mu'jam al-Wasiṭ (Cet. IV; Mesir: Maktabah al-Syurūq al-Dauliyyah, 1425 H/2004 M), h. 174.

Majma‘ al-Lugah al-‘Arabiyyah Mesir, al-Mu‘jam al-Wasīt, h. 174. Lihat juga Aḥmad Mukhtär 'Umar, Mu'jam al-Lugah al-'Arabiyyah al-Mu'āsarah, jilid I, h. 497.

Majma' al-Lugah al-'Arabiyyah Mesir, al-Mu'jam al-Wasiț, h. 86.

Muhammad ibn Ismā '̄il al-Bukhārī, Șạhịh al-Bukhārī, Jilid I (Cet. I; Mekah: Dār Ṭauq al-Najāh, 1422 H), h. 19. Selanjutnya disebut al-Bukhāri, Sahịị al-Bukhārī. Lihat juga Muslim ibn al-Ḥajjāj, Șaḥị̣ Muslim, Jilid I (Beirut: Dār al-Iḥyā' al-Turāì al-'Arabi, t.th.), h. 36. Selanjutnya disebut Muslim, Șahị Muslim.

Muhammad ibn Ismā'îl al-Bukhārí, Șaḥịh al-Bukhārì, Jilid I (Cet. I; Mekah: Dār Ṭauq al-Najāh, 1422 H), h. 19. Selanjutnya disebut al-Bukhārì, Șaḥị̣ al-Bukhārì.

Muta'addi adalah kata kerja yang awalnya tidak membutuhkan maf'ūl (objek) ketika telah di-muta'addì-kan maka menjadi kata kerja yang butuh maf'ùl.

Nurcholish Madjid, Karya Lengkap Nurcholish Madjid; Keislaman, Keindonesiaan, dan Kemodernan, ed. Budhy Munawar-Rachman (Cet. I; Jakarta: Nurcholish Madjid Society, 2019), h. 1611. Selanjutnya disebut Nurcholish, Karya Lengkap.

Russel Stannard, Tuhan Abad 21, terj. Happy Susanto (Yogyakarta: Belukar Budaya, 2004), h. 206

Umar Shihab, Kontekstualitas al-Qur'an; Kajian Tematik atas Ayat-ayat Hukum dalam al-Qur'an (Cet. I; Jakarta: Penamadani, 2003), h. xxi. 